IJEBR 23,6

Okayasu and Morais (2017), "Sport entrepreneurship and community development in Japan", in Ratten, V. and Ferreira, J. (Eds), Sport Entrepreneurship and Innovation, Routledge, Taylor \& Francis Group, London and New York, NY.

Ratten, V. (2012), "Sport entrepreneurship: challenges and directions for future research", International Journal of Entrepreneurship and Small Business, Vol. 4 No. 1, pp. 65-76.

Ratten, V. (2017), "Sport, innovation and public policy", in Ratten, V. and Ferreira, J. (Eds), Sport Entrepreneurship and Innovation, Routledge, Taylor \& Francis Group, London and New York, NY.

Ratten, V. and Ferreira, J. (Eds) (2017), Sport Entrepreneurship and Innovation, Routledge, Taylor \& Francis Group, London and New York, NY.

\begin{abstract}
About the reviewer
João Leitão is an Assistant Professor at the University of Beira Interior (UBI). He is an Associate Researcher of the Centre for Management Studies of Instituto Superior Técnico (CEG-IST), University of Lisbon and of the Center for Mechanical and Aerospace Science and Technologies (C-MAST), UBI. He is an external Research Fellow at the Kingston University, Kingston Business School, Small Business Research Centre London, UK; and at the Instituto Multidisciplinar de Empresa, Universidad de Salamanca, Spain. Previous professional appointments include positions as a Visiting Researcher at the Friedrich-Schiller-Universität Jena, Germany; Universidad Carlos III, Madrid, Spain; Università degli Studi di Napoli Federico II, Italy; and Max Planck Institute of Economics, Jena, Germany. His research interests include entrepreneurship, innovation, organisational economics and business models.
\end{abstract}

\title{
Critical Perspectives on Entrepreneurship: Challenging Dominant Discourses
}

Edited by C. Essers, P. Dey, D. Tedmanson and K. Verduyn

Routledge

London

2017

$£ 110.00 \mathrm{hbk}$

Review DOI 10.1108/IJEBR-10-2017-408

The latest edited book from Routledge's Rethinking Entrepreneurship Research series extends the work of previous volumes by seeking to question underlying assumptions in dominant forms of entrepreneurship that tend to privilege certain types of economic activity at the expense of others. In doing so, it furthers the increasingly prominent debates characterised as "critical entrepreneurship studies". The various authors question and critique the practice and dominant discourses of entrepreneurship through the adoption of a variety of critical perspectives, listening to excluded voices and acknowledging the darker aspects of entrepreneurial activities. The book is structured thematically into five parts and each part includes chapters by leading scholars in the field.

Part 1 includes three chapters that are framed as seeking to contest neoliberalism. The first two chapters discuss social enterprise, with Berglund (Chapter 2) drawing on ethnographic case studies to challenge the romanticisaton of social enterprise and emphasising its precarity and Lyne (Chapter 3) valuably extending this by exploring the experiences of social enterprises in a non-western context, indigenous villagers in Cambodia. Hanlon (Chapter 4) completes the first section of the book with a provocative and insightful chapter which argues for "growing corporate tendencies to entrepreneurially capture value that it did not create [using] property rights to make the virtually limitless scarce and the inclusive exclusive" (p. 51). This represents, for example, the capture and commodification of free or subsidised labour by companies such as Google, market power capturing and exploiting entrepreneurialism. 
The book's second part includes three chapters discussing indigenous and communitybased entrepreneurship. Weston and Imas (Chapter 5) develop their earlier work on the "barefoot entrepreneur", those on the margins of neoliberalism who Weston and Imas suggest seek to "alter our capitalist society and construct a communitarian alternative" (p. 75). In developing this debate, they highlight the importance of alternative discourses, for example through advancing indigenous perspectives, for which the authors provide examples through case studies of activities undertaken within disenfranchised communities in Argentina and Zimbabwe. Tedmanson and Evans (Chapter 6) then examine indigenous entrepreneurship in Australia, focussing on relational, collaborative forms of leadership in and social transformation. This chapter provides further argument for alternatives to mainstream, western discourses that have tended to promote "an aggressive individualism, risk taking and economic rationalism” (p. 102). de Boer and Smith (Chapter 7) present a detailed, situated analysis of small restaurants (warung) in Indonesia. They explore the "informal" activities in relation to formal institutions, maintaining "a distance from a steadily intruding global economy in the city around them" (p. 121). This section clearly establishes the value of perspectives from outside dominant western entrepreneurship discourse and suggests promising directions for future research.

The three chapters in Part 3 of the book focus on migrant entrepreneurs. Jones, Ram and Villares (Chapter 8) begin by placing the "generally uncritical celebration of migrant entrepreneurship" (p. 125) within a neoliberal discourse that portrays migrant entrepreneurs as embodying free market values. Their analysis addresses the limitations of the mixed embeddedness approach and makes the case for more comparative research in this area. Importantly, they also suggest the need for a more critical consideration of family and community ties and informal practices, for example to counteract the obscuring of "the invisible work of women and children within the ethnic economy" (Jones, Ram and Villares) and greater consideration of racial, class and gender inequality processes. The subsequent chapter (Chapter 9) by Thoelen and Zanoni explores the "crafting" of legitimacy by migrant entrepreneurs in the creative industries, taking an agent-centred approach that challenges the lack of agency often attributed to ethnic minority entrepreneurs in the academic literature. Verduyn and Essers (Chapter 10) analyse the stories of female ethnic entrepreneurs in relation to the agenda of the Dutch government as presented in interviews with relevant officials. The authors problematise the promotion of entrepreneurship as emancipatory, in particular where this is "stimulated" by the state rather something that is made sense of by the entrepreneurs in their own way. This section of the book is presented as a critique of the archetype of the white Christian entrepreneur and the critical engagement with some of the assumptions in theory, practice and policy regarding migrant entrepreneurs and the impacts of this archetype generates valuable insights.

Part 4 expands the developing critique in terms of gender. Marlow and Al-Dajani (Chapter 11) provide a valuable starting point with an overview of feminist critiques of entrepreneurship and the "embedded biases with [its] ontological foundations" (p. 179), exploring gender, context and intersectionality. Building on these types of insight, Özkazanç-Pan (Chapter 12) returns to some of the themes from Chapter 10 with a postcolonial feminist perspective on entrepreneurship and empowerment in Turkey. Together with Aygören (Chapter 13) on immigrant women entrepreneurs in Sweden, these chapters explore power and resistance and agency in important contexts. Aygören explores how the women in her study go about "reconnecting and repositioning themselves in the face of particular struggles concerning their positioning in social hierarchies and their ethical concerns" (p. 215). Crucially, entrepreneurship does not provide an unproblematic answer to such struggles.

The final part of the book includes two chapters grouped in terms of a deconstruction of entrepreneurship. These chapters do not provide a clear conclusion to the earlier work but they 
IJEBR

23,6

1076

do place some of the debates in a wider political context. Marsh and Thomas (Chapter 14) discursively analyse the neoliberal transition of Poland, drawing out the consequences of the promotion of entrepreneurship in terms of legitimising a dismantling of the welfare state and its use "to facilitate conditions for the ongoing expropriation of the commons" (p. 237). The final chapter (Chapter 15) by Skoglund, places the debate within a different political context through a discussion of ecopreneurship, problematising its "taken-for-granted goodness" (p. 258) and highlighting its potentially unknown consequences and destructiveness.

Overall, Critical Perspectives on Entrepreneurship develops a sustained critique of dominant understandings and practices of entrepreneurship, in particular in relation to the pervasive influence of neoliberalism and privileging of related types of economic activity. The collection includes an impressive range of chapters, several of the authors developing their own important, earlier work and raising important questions such as the extent to which entrepreneurship provides an unproblematic answer to exclusion or empowerment. These chapters cohere to form an important critique and platform for future critical debate. The book is a valuable addition to an interesting, thought-provoking series.

Oliver Mallett 